Western Washington University

Western CEDAR

$10-1996$

\title{
Naticid Gastropod Prey Selectivity Through Time and the Hypothesis of Escalation
}

Patricia H. Kelley

Thor A. Hansen

Western Washington University, thor.hansen@wwu.edu

Follow this and additional works at: https://cedar.wwu.edu/geology_facpubs

Part of the Geology Commons

\section{Recommended Citation}

Kelley, Patricia H. and Hansen, Thor A., "Naticid Gastropod Prey Selectivity Through Time and the Hypothesis of Escalation" (1996). Geology Faculty Publications. 2.

https://cedar.wwu.edu/geology_facpubs/2 


\title{
Naticid Gastropod Prey Selectivity Through Time and the Hypothesis of Escalation
}

\author{
PATRICIA H. KELLEY \\ Department of Geology and Geological Engineering, University of North Dakota, Grand Forks, ND 58202-8358 \\ THOR A. HANSEN \\ Department of Geology, Western Washington University, Bellingham, WA 98225
}

PALAIOS, 1996, V. 11, p. 437-445

The hypothesis of escalation posits that biologic hazards such as predation have increased during the Phanerozoic. Previously, a survey of drilling frequencies in the Cretaceous and Paleogene of the North American Coastal Plain suggested an episodic pattern of escalation within the naticid gastropod predator-prey system. This study examines escalation from the perspective of naticid prey selectivity. If escalation occurred within the system, less selectivity of prey may be apparent in the Paleogene compared to younger assemblages. We test this hypothesis for four Eocene Coastal Plain assemblages.

Contrary to predictions, intraspecific prey size selectivity was well developed for nine of eleven bivalve prey species. Drillhole size (indicating predator size) correlated significantly with prey size, especially for successful drillholes. Few incomplete or nonfunctional drillholes occurred, except within corbulid species.

Interspecific prey selectivity was less developed than for Neogene or Recent assemblages. Naticid prey preferences predicted by cost-benefit analysis were consistent with actual drilling frequencies only for the Bashi Marl Member of the Hatchetigbee Formation (Alabama). In the Piney Point Formation of Virginia, all prey items were drilled at equivalent frequencies, despite their different cost-benefit rankings. Upper Lisbon (Alabama) and Moodys Branch (Mississippi and Louisiana) assemblages showed limited agreement with preferences predicted by cost-benefit analysis. Prey selectivity thus appears less developed in the Paleogene compared to the Neogene and Recent, in accordance with the hypothesis of escalation.

\section{INTRODUCTION}

In his 1987 book on Evolution and Escalation, Vermeij hypothesized that adaptation to enemies has been a key theme of Phanerozoic evolution. Thus, according to Vermeij $(1987,1994)$, the history of life has been characterized by escalation: increasing severity of biologic hazards and greater expression of aptations to such hazards. Escalation has been claimed to characterize predator-prey systems, including those of drilling gastropods. Vermeij (1987) supported this claim with evidence on temporal changes in drilling frequencies and the occurrence of mobile or well-armored gastropods and bivalves with tight valve closure.

Drilling gastropod predators on molluscs include the Muricidae and the Naticidae. This study focuses on naticid predation. Naticids are infaunal gastropods that first became important drillers of molluses in the Cretaceous (Sohl, 1969). Data on naticid predation are readily available from fossil assemblages; drillhole size and morphology record size and family affinity of the predator, and whether an attack was successful or not.

The naticid gastropod predator-prey system thus provides an excellent opportunity for testing the hypothesis of escalation. Vermeij (1987) suggested that drilling predation escalated significantly between the Cretaceous and sometime in the Eocene. In order to test this hypothesis of escalation, we have conducted a comprehensive survey of naticid predation within the Cretaceous and Paleogene of the U.S. Gulf and Atlantic Coastal Plain. Data have been tabulated for more than 46,000 specimens from a temporal succession of fourteen stratigraphic levels (17 formations). Previously, we reported data on drilling frequencies in space (Hansen and Kelley, 1995) and time (Kelley and Hansen, 1993). In general, our results suggested episodic changes in drilling through time, with acceleration of drilling frequencies following mass extinctions. We also documented temporal patterns in incomplete and multiple drilling, which indicate unsuccessful attacks, and in drillhole site selectivity (Kelley and Hansen, 1993); relative effectiveness of prey defenses apparently increased during the Paleogene.

The present study focuses on escalation from the per- 
spective of naticid prey selectivity. Extant naticids are selective of prey size (Kitchell et al., 1981) and prey species (Edwards, 1974; Wiltse, 1978; Kitchell et al., 1981). Boggs et al. (1984) determined that this selectivity is highly stereotyped. Extant naticids do not evaluate prey based on individual experiences; prey preferences instead are longterm responses developed over evolutionary time.

Prey selectivity maximizes net energy return, and for extant naticids is predictable by cost-benefit analysis (Kitchell et al., 1981). Cost associated with a particular prey item is a function of drilling time and thus is correlated with prey shell thickness. Benefit depends on biomass, which can be represented as internal volume of the shell. Predators are predicted to choose prey items with the lowest cost-benefit (thickness:internal volume) ratio; this ratio generally decreases within a species with increasing prey size. Cost-benefit analyses successfully predicted naticid prey preferences within several Neogene (Kitchell et al., 1981; Kelley, 1988, 1991) as well as modern assemblages.

Kelley (1988) also found a relationship between drilling success and selectivity of prey in Miocene Chesapeake Group assemblages. The greatest percentage of successful attacks occurred on prey taxa for which naticids showed the most selectivity of prey size and drillhole site. These results suggest that selectivity by the predator promotes greater efficiency of predation.

Previous work (Kelley and Hansen, 1993; Hansen and Kelley, 1995) indicated some selectivity of naticid prey species in the Paleogene. For instance, in the Bashi Marl Member of the Hatchetigbee Formation, the corbulids Corbula subengonata and Vokesula aldrichi were preferred as prey. Lucina pomilia (lucinid, Piney Point Formation) and Pachecoa decisa (noetiid, upper Lisbon Formation) were also identified by Hansen and Kelley (1995) as preferred prey species. In the Moodys Branch Formation, preferred bivalve prey included the corbulid Caestocorbula wailesiana and the lucinids Gonimyrtaea curta and G. subcurta (Hansen and Kelley, 1995). In general, species of the families Turritellidae, Lucinidae, and Corbulidae usually suffered predation at levels disproportionate to their representation in an assemblage (Kelley and Hansen, 1993). Thus some evidence for prey selectivity exists for the Paleogene. However, cost-benefit analysis is necessary to determine if the same "rules" governed prey choice in the Paleogene, and if the same level of predator behavioral stereotypy was present.

If escalation has characterized the naticid predatorprey system, naticid interactions with their prey may have changed through time. The escalation hypothesis suggests that the biological hazard of naticid predation increased through time; because selectivity of prey has been shown to improve predator efficiency, we suggest that the hazard of naticid predation may have escalated through increased behavioral stereotypy. In that case, less selectivity of prey size and species may be apparent in Paleogene assemblages than in Neogene and modern samples. We test this hypothesis for several assemblages from our Paleogene data set.

\section{MATERIALS AND METHODS}

\section{Materials}

In order to compare consistently the cost-benefit ratios of different prey items, we confined our study to bivalve prey. Adequate numbers of specimens of at least two bivalve species, preferably with different drilling frequencies, were needed from a stratigraphic level for cost-benefit analysis. We also required that specimens come from bulk samples.

Not all of the fourteen stratigraphic levels included in our survey of drilling frequencies met our requirements for cost-benefit analysis. For instance, no Cretaceous levels could be included in the study; the Ripley and Providence samples (collected by Norman Sohl, U.S. Geological Survey) were not bulk samples, and preservation in the Corsicana was too poor and drillholes too rare (none of the abundant species, i.e., with more than 20 specimens, was drilled). Of the Paleocene levels, drilling on bivalves was too rare in the Kincaid and Bells Landing. Within the Matthews Landing, although Turritella aldrichi was abundant and highly preferred as prey, no bivalve species were abundant enough for cost-benefit analysis. Sample sizes for Oligocene bivalve prey also were marginal for this type of analysis.

We therefore focused our analyses on four assemblages of Eocene age. The Bashi Marl Member of the Hatchetigbee Formation (lower Eocene) was collected from the bank of Spear Creek behind the Patrician Academy field, Route 17 south of Butler, Choctaw County, Alabama. Cost-benefit analysis of the Bashi compared Venericardia horatiana, Corbula subengonata, and Vokesula aldrichi. Although all three species suffered significant predation by naticids, the two corbulid species (C. subengonata and V. aldrichi) were particularly favored as prey. The percentage of individuals with complete naticid drillholes (determined from our comprehensive survey) was as follows for those three species: V. horatiana, $37.5 \%$; C. subengonata, $60.8 \%$; V. aldrichi, $47.9 \%$.

Two upper middle Eocene assemblages were examined. Samples were collected from the Piney Point Formation along the Pamunkey River, Virginia, and from the upper Lisbon Formation of Alabama. Upper Lisbon samples were taken from exposures on Little Stave Creek and the Alabama and Conecuh Rivers, and from a road cut near Barryton in Choctaw County. Our analysis of the Piney Point Formation included Lucina pomilia and Callista perovata. As was typical of lucinids in our survey, $L$. pomilia was very heavily drilled (53.5\% mortality), while $27.5 \%$ of Callista individuals had complete naticid drillholes. The upper Lisbon analysis compared Pachecoa decisa (41.8\% drilled) and Corbula extenuata (20.6\% drilled).

Four species were compared from the upper Eocene Moodys Branch Formation of Louisiana and Mississippi: Gonimyrtaea subcurta (the most heavily drilled constituent of the fauna, with $38.1 \%$ of all individuals drilled), Gonimyrtaea curta (18.6\% drilled), Caestocorbula wailesiana $(21.8 \%$ drilled), and Spisula jacksonensis $(4.6 \%$ 
drilled). Our Moodys Branch sample includes assemblages from six different subenvironments (Elder and Hansen, 1981). However, Hansen and Kelley (1995) demonstrated no systematic differences in drilling among subenvironments within the Moodys Branch. Thus, in this study, we have combined samples from the different subenvironments in order to increase sample sizes for each prey class. Hansen and Kelley (1995) provided further details on the Moodys Branch, Piney Point, and upper Lisbon samples.

Hansen and Kelley (1995) also discussed the potential problem of taphonomic bias of drilling frequencies in these Eocene assemblages. Roy et al. (1994) demonstrated experimentally that drilled specimens of modern Mulinia are more likely to break under compressive forces than are undrilled specimens. They concluded that selective breakage of drilled shells could thus alter drilling frequencies in fossil assemblages and provided criteria to use in testing for such bias. We applied these criteria to the samples used here and found that, although fragmented shells are common, breakage through drillholes is rare. These observations, along with the excellent preservation of these deposits, suggest that taphonomic bias should be minimized (Hansen and Kelley, 1995).

\section{Methods}

Shell length (L) was measured for all specimens of each species studied. Two additional characters were measured on a randomly selected subsample of specimens: thickness (TH) at an equivalent point on each valve (near the margin, for practical purposes), and internal volume (IV). These two variables were used only to define the cost-benefit curves; it was not necessary to measure all specimens for species with a large sample size and a well-constrained cost-benefit relation.

Characteristics of each drillhole were also recorded. Shape of the drillhole generally indicates the taxonomic affinity of the driller (although edge-drilled holes and those in very thin shells may be difficult to identify; Kowalewski, 1993). Naticid holes tend to be parabolic in cross section (Oichnus paraboloides of Bromley, 1981), whereas muricid holes are straight sided (Oichnus simplex of Bromley, 1981; see also Carriker, 1981). Outer borehole diameter (OBD), which is correlated with predator size (Kitchell et al., 1981), was measured for all drillholes. For complete drillholes, which penetrate to the shell interior, inner borehole diameter (IBD) was also measured. The IBD: OBD ratio indicates whether a complete drillhole was functional (Kitchell et al., 1986); a ratio less than about 0.5 implies that the inner borehole diameter probably was not enlarged enough for passage of the proboscis. Finally, drillhole site was recorded with respect to a nine-sector grid employed by Kelley (1988), Anderson et al. (1991), and Anderson (1992); see also Kelley and Hansen (1993). Chi-squared tests were used to identify, for each prey species, sites on the shell that normally were preferred for drilling by naticids. In performing these chi-squared tests we followed Anderson (1992), calculating expected drilling frequencies as proportional to the surface area of each sector.

Previous authors have examined size selectivity by comparing prey size to borehole diameter (Kitchell et al., 1981; Kitchell, 1986; Kelley, 1988, 1991). Using Quattro Pro, we plotted OBD of naticid drillholes (as a measure of predator size) vs. L (prey size) for each prey species. We calculated least-squares regressions and correlation coefficients to determine if a significant relationship exists between the two variables. The $\mathrm{P}$-value used for significance tests was 0.05. Following Kelley (1988) we analyzed complete holes, functional holes, normally sited holes (identified by the chi-squared tests mentioned above), and all holes separately. We expected that each of these categories of drillholes might differ in the strength of correlation of OBD and L. For instance, Kitchell et al. (1981) observed abnormal drillhole sitings to result from attacks on too large or too small prey; incomplete or nonfunctional drillholes might also result from a mismatch of predator and prey sizes (Kelley, 1988).

We performed cost-benefit analyses, following Kitchell et al. (1981) and as detailed by Kelley (1988, 1991). The methods are summarized briefly here. For each species to be compared within a stratigraphic level, we obtained cost-benefit curves by regressing $\log _{10}(\mathrm{TH} / \mathrm{IV})$ vs. L using Quattro Pro. Because different-sized predators should have different prey preferences, analysis was conducted for a specific predator size (i.e., a specific range of $O B D$ ). All taxa studied showed a concentration of drillholes in the 0.5-1.0 $\mathrm{mm}$ size range; this OBD range was used in all the analyses. Because predators are unable to manipulate prey individuals exceeding a certain size, we determined this "escape size" for each prey species based on the largest specimen with a successful drillhole in the $0.5-1.0 \mathrm{~mm}$ OBD range. (The escape size represents an inflection point in the curve, where the cost: benefit ratio skyrockets to infinity as the probability of successful predation drops to zero.) Predator preferences were then predicted, assuming that a predator should select the prey item with the lowest cost: benefit ratio in the size range it can handle. Predictions were compared with actual drilling frequency for each prey item, and chi-squared tests were used to determine significance of differences in drilling between items. The P-value used to test for significance was 0.05 .

\section{RESULTS}

\section{Intraspecific Prey Size Selectivity}

Results of the analysis of intraspecific prey size selectivity are presented in Table 1 . Naticid predation on most species was size selective, at least for complete and functional drillholes.

Strong size selectivity occurred for the Bashi species Venericardia horatiana. All naticid drillholes were complete and functional, and the correlation between shell length and $\mathrm{OBD}$ was significant $(\mathrm{r}=0.7289, \mathrm{P}<0.001)$. When only normally sited drillholes (for this species, those situated along the ventral region of the valve) were consid- 
TABLE 1-Size selectivity and predation success.

\begin{tabular}{|c|c|c|c|c|c|c|}
\hline \multirow[b]{2}{*}{$\begin{array}{l}\text { Stratigraphic } \\
\text { unit }\end{array}$} & \multirow[b]{2}{*}{ Taxon } & \multicolumn{4}{|c|}{ Correlation } & \multirow[b]{2}{*}{$\begin{array}{l}\text { Success } \\
\text { rate }\end{array}$} \\
\hline & & $\begin{array}{c}\text { All } \\
\text { holes }\end{array}$ & $\begin{array}{c}\text { Complete } \\
\text { holes }\end{array}$ & $\begin{array}{l}\text { Funct. } \\
\text { holes }\end{array}$ & $\begin{array}{l}\text { Normal } \\
\text { holes }\end{array}$ & \\
\hline \multirow[t]{3}{*}{ Bashi } & Corbula subengonata & 0.0021 & 0.0859 & 0.0859 & 0.1925 & $18 / 27=0.67$ \\
\hline & Venericardia horatiana & $0.7289 * * *$ & $0.7289 * * *$ & $0.7289 * * *$ & $0.8028 * * *$ & $57 / 57=1.00$ \\
\hline & Vokesula aldrichi & 0.2680 & $0.5168 *$ & $0.5555^{*}$ & 0.4092 & $19 / 25=0.76$ \\
\hline \multirow[t]{2}{*}{ Piney Point } & Callista perovata & $0.6689 *$ & $0.6689^{*}$ & $0.6689 *$ & $0.8648^{*}$ & $11 / 11=1.00$ \\
\hline & Lucina pomilia & $0.3057^{*}$ & $0.3207^{*}$ & $0.3207^{*}$ & $0.3391^{*}$ & $57 / 58=0.98$ \\
\hline \multirow[t]{2}{*}{ Upper Lisbon } & Corbula extenuata & $0.4630 * *$ & $0.4167^{*}$ & $0.4377^{*}$ & 0.1557 & $29 / 34=0.85$ \\
\hline & Pachecoa decisa & $0.5965^{* * *}$ & $0.5990^{* * *}$ & $0.6243^{* * *}$ & $0.6505^{* * *}$ & $77 / 84=0.92$ \\
\hline \multirow[t]{4}{*}{ Moodys Branch } & Caestocorbula wailesiana & 0.1222 & $0.5687^{*}$ & $0.5687^{*}$ & - & $14 / 19=0.74$ \\
\hline & Gonimyrtaea curta & 0.0147 & 0.0147 & 0.0438 & 0.1625 & $16 / 17=0.94$ \\
\hline & Gonimyrtaea subcurta & $0.5148^{* *}$ & $0.5265^{* * *}$ & $0.5265^{* * *}$ & $0.4520^{*}$ & $35 / 35=1.00$ \\
\hline & Spisula jacksonensis & $0.7902 * *$ & $0.7902^{* *}$ & $0.7902^{* *}$ & $0.7756^{* *}$ & $12 / 12=1.00$ \\
\hline
\end{tabular}

Correlation coefficients for outer borehole diameter vs. prey length for complete, functional (funct.), normal-sited, and all holes.

P-values: * $0.05,{ }^{* *} 0.01, * * * 0.001$.

Success rate $=$ number of functional holes/all holes.

ered, the correlation was $0.8028(\mathrm{P}<0.001)$. Vokesula aldrichi showed a significant correlation between shell length and drillhole size for complete holes and for functional holes. However, when incomplete as well as complete holes were included, the correlation dropped to a nonsignificant 0.2680 . (Five of 20 drillholes measured in this analysis were incomplete.) The correlation was also nonsignificant for the fifteen normally sited, complete holes. A third of the holes measured for Corbula subengonata from the Bashi were incomplete, although all complete holes were functional. None of the correlations between length and OBD (for all holes, complete/functional holes, or normally sited holes) was significant at the 0.05 level.

Within the Piney Point Formation, intraspecific size selectivity occurred for both prey species examined. All drillholes examined in this study in Callista perovata and all but one in Lucina pomilia were complete and functional, and a significant correlation occurred between OBD and shell length for both species. Six drillholes were considered normally sited (in the dorsal region of the shell) in $C$. perovata, and these also showed a significant correlation between OBD and L. Three-fourths of $L$. pomilia drillholes occurred along the midline perpendicular to the anteriorposterior axis; these normally sited drillholes were significantly correlated in diameter with shell length at the 0.05 level.

Both species studied from the upper Lisbon of Alabama displayed significant correlations of OBD and length. Nearly all drillholes on Pachecoa decisa were complete, and most complete holes were functional. About threefourths of all drillholes were positioned along the midline of the valve perpendicular to the anterior-posterior axis. All categories of drillholes showed correlations between OBD and L that were significant. Corbula extenuata showed a higher percentage of incomplete (12\%) and non- functional (15\%) drillholes, and a broader distribution of drillhole sites. All classes of drillholes showed a significant correlation between OBD and L, with the exception of normally sited holes. The broader distribution of holes made it difficult to identify a normal site for drilling; seven holes in the dorsal region did not show a significant correlation of OBD and L.

In the Moodys Branch Formation, Gonimyrtaea subcur$t a$ and Spisula jacksonensis showed selectivity of prey size for all drillhole categories. All holes measured for $S$. jacksonensis were complete and functional, and $83 \%$ occurred near the umbones. Gonimyrtaea subcurta drillholes were similarly located, and all were complete. In contrast, only $74 \%$ of drillholes measured for Caestocorbula wailesiana were complete, though all of those were functional. Drillholes were fairly broadly distributed, with no statistically significant preference for any region of the valves; thus no "normal" drilling site could be identified. The correlation between $\mathrm{OBD}$ and $\mathrm{L}$ was significant $(\mathrm{r}=0.5687, \mathrm{P}<0.05)$ for complete/functional holes, but was not significant when incomplete holes were included. All drillholes measured on Gonimyrtaea curta were complete, and all but one were functional. The majority $(59 \%)$ occurred in the center of the valves. None of the correlation coefficients calculated for $\mathrm{OBD}$ and $\mathrm{L}$ was significant at the 0.05 level.

\section{Cost-Benefit Analysis}

Selectivity of prey species occurred within the lower Eocene Bashi Marl Member of the Hatchetigbee Formation. Figure 1 shows the cost-benefit functions and inflection points for each species. Predicted preferences of naticids with an outer borehole diameter of 0.5-1.0 mm are shown in Table 2 . The prey item with the lowest cost-benefit ratio is Venericardia horatiana of $5.36-6.42 \mathrm{~mm}$ length; this 


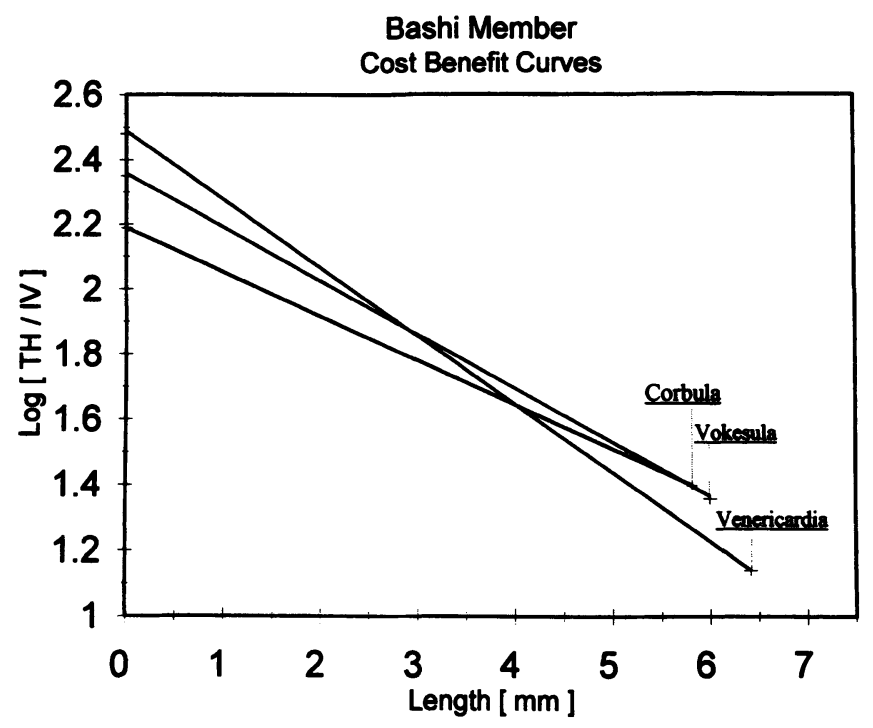

FIGURE 1-Cost-benefit curves for the Bashi Member of the Hatchetigbee Formation. $\mathrm{TH}=$ thickness, $\mathrm{IV}=$ internal volume, and $\mathrm{L}=$ length. $\log _{10}(T H / I V)$ in $\mathrm{mm} / \mathrm{ml}$ is plotted vs. length in $\mathrm{mm}$. Inflection points for a predator with OBD (outer borehole diameter) of $0.5-1.00$ $\mathrm{mm}$ are: Venericardia horatiana, $6.42 \mathrm{~mm}$; Corbula subengonata, 5.82 $\mathrm{mm}$; Vokesula aldrichi, $6.00 \mathrm{~mm}$.

item was thus predicted to be ranked first by the predator. Unfortunately, only 15 specimens, including one drilled specimen, occurred in that size range, and drilling frequency for this item did not differ from that of any other item at the 0.05 significance level. In general, however, prey items predicted to be ranked second by the predator were drilled more frequently than items predicted to be ranked third. For instance, third-ranked Vokesula aldrichi (2.70-4.20 mm length) exhibited significantly less drilling than second-ranked $V$. aldrichi of 4.20-6.00 mm length $\left(\chi^{2}\right.$ $=3.89, \mathrm{P}<0.05)$ and Corbula subengonata of 3.90-5.82 mm length $\left(\chi^{2}=6.17, \mathrm{P}<0.02\right)$. Likewise, third-ranked Venericardia horatiana $(2.70-3.90 \mathrm{~mm})$ was drilled less frequently than second-ranked Corbula subengonata of

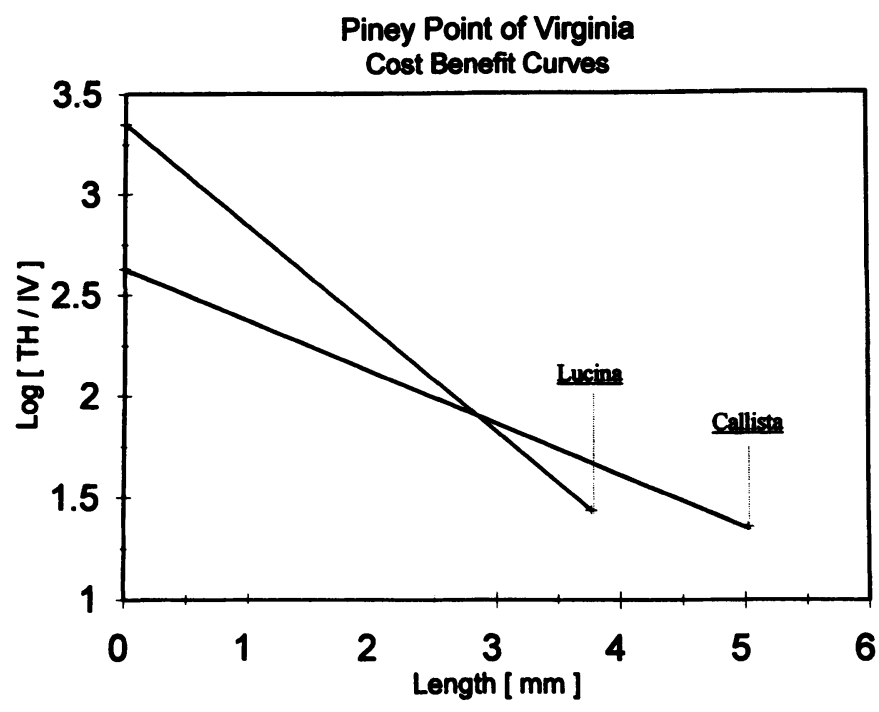

FIGURE 2-Cost-benefit curves for the Piney Point Formation. TH = thickness, IV $=$ internal volume, and $L=$ length. $\log _{10}(T H / I V)$ in $\mathrm{mm} / \mathrm{ml}$ is plotted vs. length in $\mathrm{mm}$. Inflection points for a predator with OBD (outer borehole diameter) of $0.5-1.00 \mathrm{~mm}$ are: Callista perovata, $5.03 \mathrm{~mm}$; Lucina pomilia, $3.77 \mathrm{~mm}$.

$3.90-5.82 \mathrm{~mm}$ length $\left(\chi^{2}=6.29, \mathrm{P}<0.02\right)$. Drilling frequencies on items predicted to rank second ranged from $0.300-0.610$; drilling frequencies on third-ranked items ranged from $0.138-0.280$.

The occurrence of drillholes in the size range of 0.5-1.0 mm was compared for two Piney Point species, Callista perovata and Lucina pomilia (Fig. 2, Table 3). Regardless of cost-benefit ratio, most prey classes were drilled at about the same intensity (17-22\%). No prey item differed significantly in drilling frequency from any other item, based on chi-squared tests ( 0.05 probability level). Chisquared values ranged from 0.002 to 1.955 .

The Piney Point equivalent in Alabama is the upper Lisbon Formation. Cost-benefit functions are illustrated in Figure 3; a linear regression was used for the Pachecoa de-

TABLE 2-Predicted preferences of naticids from the Bashi Member of the Hatchetigbee Formation with OBD (outer borehole diameter) $=0.5-1.0 \mathrm{~mm}$.

\begin{tabular}{|c|c|c|c|c|c|}
\hline \multirow{2}{*}{$\begin{array}{l}\text { Predicted } \\
\text { rank }\end{array}$} & \multicolumn{2}{|c|}{ Prey } & \multirow[b]{2}{*}{$\mathrm{D}$} & \multirow[b]{2}{*}{$\mathrm{N}$} & \multirow{2}{*}{$\begin{array}{l}\text { Drilling } \\
\text { frequency }\end{array}$} \\
\hline & Taxon & Size $(\mathrm{mm})$ & & & \\
\hline 1 & Venericardia horatiana & $5.36-6.42$ & 1 & 15 & 0.133 \\
\hline 2 & $\begin{array}{l}\text { Venericardia horatiana } \\
\text { Vokesula aldrichi } \\
\text { Corbula subengonata }\end{array}$ & $\begin{array}{l}3.90-5.36 \\
4.20-6.00 \\
3.90-5.82\end{array}$ & $\begin{array}{r}6 \\
17 \\
18\end{array}$ & $\begin{array}{l}40 \\
71 \\
59\end{array}$ & $\begin{array}{l}0.300 \\
0.479 \\
0.610\end{array}$ \\
\hline 3 & $\begin{array}{l}\text { Venericardia horatiana } \\
\text { Vokesula aldrichi } \\
\text { Corbula subengonata }\end{array}$ & $\begin{array}{l}2.70-3.90 \\
2.70-4.20 \\
2.10-3.90\end{array}$ & $\begin{array}{r}14 \\
2 \\
1\end{array}$ & $\begin{array}{r}100 \\
29 \\
10\end{array}$ & $\begin{array}{l}0.280 \\
0.138 \\
0.200\end{array}$ \\
\hline
\end{tabular}

$\mathrm{D}=$ number of specimens with a functional naticid drillhole, $\mathrm{N}=$ number of valves, drilling frequency $=2 \mathrm{D} / \mathrm{N}$. 
TABLE 3-Predicted preferences of naticids from the Piney Point Formation of Virginia with OBD (outer borehole diameter) $=0.5-1.0 \mathrm{~mm}$.

\begin{tabular}{clcrrrr}
\hline \hline $\begin{array}{c}\text { Pre- } \\
\text { dict- } \\
\text { ed } \\
\text { rank }\end{array}$ & \multicolumn{2}{c}{ Prey } & & & & $\begin{array}{c}\text { Dril- } \\
\text { ling } \\
\text { fre- }\end{array}$ \\
\cline { 2 - 3 } 1 & Callista perovata & $4.60-5.03$ & 1 & 9 & 0.222 \\
2 & Callista perovata & $2.85-4.60$ & 4 & 47 & 0.170 \\
& Lucina pomilia & $2.85-3.77$ & 8 & 74 & 0.216 \\
3 & Callista perovata & $1.00-2.85$ & 0 & 13 & 0.000 \\
& Lucina pomilia & $1.90-2.85$ & 14 & 128 & 0.219 \\
4 & Lucina pomilia & $<1.90$ & 1 & 7 & 0.286 \\
\hline
\end{tabular}

$\mathrm{D}=$ number of specimens with a functional naticid drillhole, $\mathrm{N}=$ number of valves, drilling frequency $=2 \mathrm{D} / \mathrm{N}$.

cisa data, but a curve was fitted by eye to the Corbula extenuata data. Some evidence for prey selectivity is apparent (Table 4). The item predicted to be ranked first, Corbula extenuata $(4.50-6.92 \mathrm{~mm})$, was drilled at a significantly greater frequency than any lower-ranked item except $P$. decisa $3.00-4.30 \mathrm{~mm}$ (chi-squared values range from 6.24 to 17.29 ). In addition, third-ranked $P$. decisa $(3.00-4.30 \mathrm{~mm})$ was preferred over fourth-ranked $P$. decisa smaller than $3.00 \mathrm{~mm}\left(\chi^{2}=14.07, \mathrm{P}<0.001\right)$. However, second-ranked $C$. extenuata $(3.35-4.50 \mathrm{~mm})$ was drilled significantly less frequently than third-ranked $P$. decisa $(3.00-4.30 \mathrm{~mm})$, contrary to predictions $\left(\chi^{2}=4.26, \mathrm{P}<\right.$

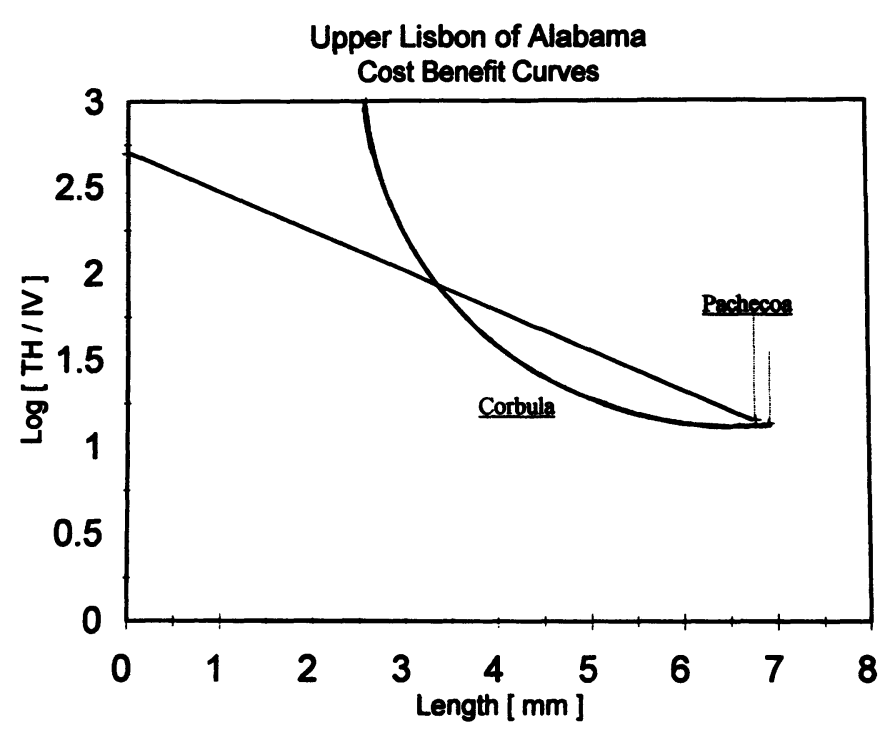

FIGURE 3-Cost-benefit curves for the upper Lisbon Formation. TH $=$ thickness, $I V=$ internal volume, and $L=$ length. $\log _{10}(T H / I V)$ in $\mathrm{mm} / \mathrm{ml}$ is plotted vs. length in $\mathrm{mm}$. Inflection points for a predator with OBD (outer borehole diameter) of $0.5-1.00 \mathrm{~mm}$ are: Pachecoa decisa, $6.78 \mathrm{~mm}$; Corbula extenuata, $6.92 \mathrm{~mm}$.
TABLE 4-Predicted preferences of naticids from the Upper Lisbon Formation of Alabama with OBD (outer borehole diameter) $=0.5-1.0 \mathrm{~mm}$.

\begin{tabular}{clcrrrr}
\hline \hline $\begin{array}{c}\text { Pre- } \\
\text { dict- } \\
\text { ed } \\
\text { rank }\end{array}$ & \multicolumn{2}{c}{ Prey } & & & & $\begin{array}{c}\text { Dril- } \\
\text { ling } \\
\text { fre- }\end{array}$ \\
\cline { 2 - 3 } 1 & Taxon & Size (mm) & D & N & quency \\
\hline & Corbula extenuata & $4.50-6.78$ & 2 & 15 & 0.267 \\
2 & Pachecoa decisa & $4.30-6.00$ & 7 & 45 & 0.578 \\
& Corbula extenuata & $3.35-4.50$ & 11 & 67 & 0.209 \\
3 & Pachecoa decisa & $3.00-4.30$ & 37 & 175 & 0.424 \\
& Corbula extenuata & $3.00-3.35$ & 1 & 31 & 0.065 \\
4 & Pachecoa decisa & $<3.00$ & 7 & 125 & 0.112 \\
\hline
\end{tabular}

$\mathrm{D}=$ number of specimens with a functional naticid drillhole, $\mathrm{N}=$ number of valves, drilling frequency $=2 \mathrm{D} / \mathrm{N}$.

$0.05)$. In addition, the two third-ranked items $(P$. decisa $3.00-4.30 \mathrm{~mm}$ and $C$. extenuata $3.00-3.35 \mathrm{~mm}$ ) were drilled at significantly different frequencies $\left(\chi^{2}=5.62, \mathrm{P}\right.$ $<0.025$ ). Drilling on first-ranked $P$. decisa was not significantly different from that on any other prey item, because of the small sample size (two of 15 specimens drilled).

Within the Moodys Branch Formation, cost-benefit analysis (Figure 4, Table 5) predicted that naticids should prefer Gonimyrtaea subcurta of $4.65-5.03 \mathrm{~mm}$ length. As predicted, drilling frequency for this prey item was greater

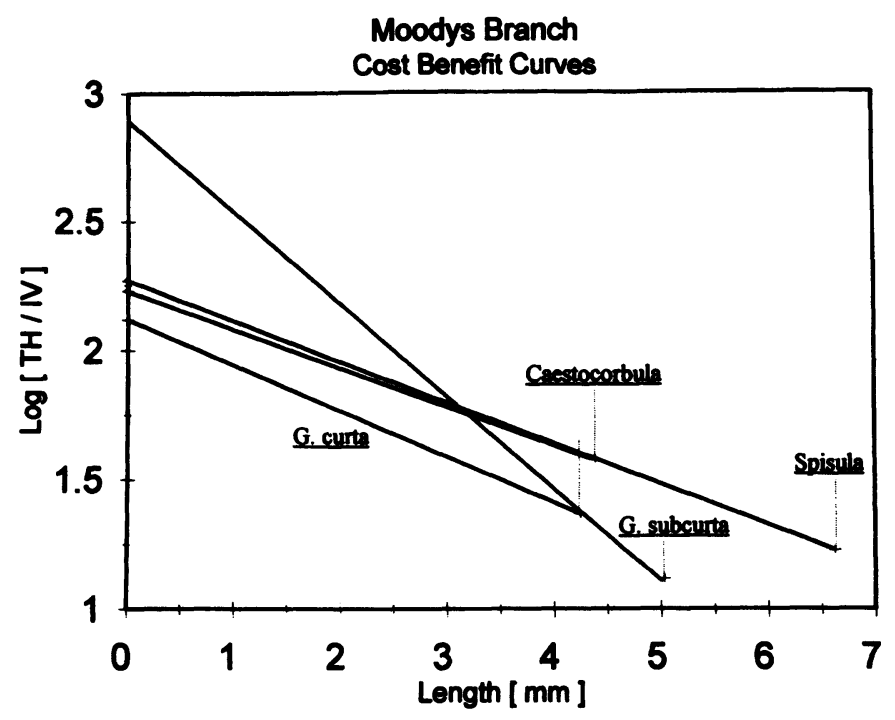

FIGURE 4-Cost-benefit curves for the Moodys Branch Formation. $\mathrm{TH}=$ thickness, $\mathrm{IV}=$ internal volume, and $\mathrm{L}=$ length. $\log _{10}(\mathrm{TH} / \mathrm{IV})$ in $\mathrm{mm} / \mathrm{ml}$ is plotted vs. length in $\mathrm{mm}$. Inflection points for a predator with OBD (outer borehole diameter) of $0.5-1.00 \mathrm{~mm}$ are: Gonimyrtaea subcurta, $5.03 \mathrm{~mm}$; Spisula jacksonensis, $6.63 \mathrm{~mm}$; Gonimyrtaea curta, $4.25 \mathrm{~mm}$; Caestocorbula wailesiana, $4.39 \mathrm{~mm}$. 
TABLE 5-Predicted preferences of naticids from the Moodys Branch Formation with OBD (outer borehole diameter) $=0.5-1.0 \mathrm{~mm}$.

\begin{tabular}{|c|c|c|c|c|c|}
\hline \multirow{2}{*}{$\begin{array}{l}\text { Predicted } \\
\text { rank }\end{array}$} & \multicolumn{2}{|c|}{ Prey } & \multirow[b]{2}{*}{$\mathrm{D}$} & \multirow[b]{2}{*}{$\mathrm{N}$} & \multirow{2}{*}{$\begin{array}{l}\text { Drilling } \\
\text { frequency }\end{array}$} \\
\hline & Taxon & Size $(\mathrm{mm})$ & & & \\
\hline 1 & Gonimyrtaea subcurta & $4.65-5.03$ & 1 & 6 & 0.333 \\
\hline 2 & $\begin{array}{l}\text { Gonimyrtaea subcurta } \\
\text { Spisula jacksonensis }\end{array}$ & $\begin{array}{l}4.35-4.65 \\
5.95-6.63\end{array}$ & $\begin{array}{l}0 \\
1\end{array}$ & $\begin{array}{r}7 \\
50\end{array}$ & $\begin{array}{l}0.000 \\
0.040\end{array}$ \\
\hline 3 & $\begin{array}{l}\text { Gonimyrtaea subcurta } \\
\text { Spisula jacksonensis } \\
\text { Gonimyrtaea curta }\end{array}$ & $\begin{array}{l}3.75-4.35 \\
4.50-5.95 \\
3.05-4.25\end{array}$ & $\begin{array}{l}5 \\
3 \\
4\end{array}$ & $\begin{array}{r}35 \\
105 \\
85\end{array}$ & $\begin{array}{l}0.286 \\
0.057 \\
0.094\end{array}$ \\
\hline 4 & $\begin{array}{l}\text { Gonimyrtaea subcurta } \\
\text { Spisula jacksonensis } \\
\text { Gonimyrtaea curta } \\
\text { Caestocorbula wailesiana }\end{array}$ & $\begin{array}{l}3.10-3.75 \\
3.05-4.50 \\
1.80-3.05 \\
2.85-4.39\end{array}$ & $\begin{array}{r}7 \\
5 \\
6 \\
12\end{array}$ & $\begin{array}{r}71 \\
118 \\
118 \\
97\end{array}$ & $\begin{array}{l}0.197 \\
0.085 \\
0.102 \\
0.247\end{array}$ \\
\hline 5 & $\begin{array}{l}\text { Gonimyrtaea subcurta } \\
\text { Spisula jacksonensis } \\
\text { Gonimyrtaea curta } \\
\text { Caestocorbula wailesiana }\end{array}$ & $\begin{array}{l}2.55-3.10 \\
1.70-3.05 \\
0.70-1.80 \\
1.50-2.85\end{array}$ & $\begin{array}{l}9 \\
1 \\
0 \\
0\end{array}$ & $\begin{array}{l}81 \\
97 \\
52 \\
23\end{array}$ & $\begin{array}{l}0.222 \\
0.021 \\
0.000 \\
0.000\end{array}$ \\
\hline
\end{tabular}

$\mathrm{D}=$ number of specimens with a functional naticid drillhole, $\mathrm{N}=$ number of valves, drilling frequency $=2 \mathrm{D} / \mathrm{N}$.

than for any other class of prey. (Because of small sample sizes, however, the difference is statistically significant only for 1.70-3.05 mm Spisula jacksonensis, 0.70-1.80 mm Gonimyrtaea curta, and 1.50-2.85 mm Caestocorbula wailesiana.) In general, all size classes of $G$. subcurta were favored as naticid prey (with the exception of the 4.35$4.65 \mathrm{~mm}$ size class, which contained only 7 specimens). For instance, third-ranked G. subcurta $3.75-4.35 \mathrm{~mm}$ were significantly preferred over all size classes of Spisula jacksonensis and over fifth-ranked Gonimyrtaea curta of $0.70-1.80 \mathrm{~mm}$ length (chi-squared values range from 4.46 to $10.41, \mathrm{P}<0.05$ or better).

In contrast to cost-benefit predictions, Spisula jacksonensis of all size ranges were drilled at equivalent, and low, frequencies $(0.02-0.09)$. With the exception of the undrilled fifth-ranked Gonimyrtaea curta and Caestocorbula wailesiana, drilling frequencies for Spisula jacksonensis were lower than for any other prey item. Such low drilling frequencies across all size classes of $S$. jacksonensis were not predicted by cost-benefit analysis.

Gonimyrtaea curta also exhibited relatively low drilling frequencies that did not differ significantly among size classes, despite their different cost-benefit rankings. In comparison, drilling on fourth-ranked Caestocorbula wailesiana $(2.85-4.39 \mathrm{~mm}$ ) was anomalously high. Based on cost-benefit ratios, C. wailesiana $(2.85-4.39 \mathrm{~mm})$ and $G$. curta $(1.80-3.05 \mathrm{~mm})$ should have been drilled at equal frequencies. Instead, $C$. wailesiana had a significantly greater drilling frequency $\left(0.247\right.$ vs. $0.102, \chi^{2}=4.11, \mathrm{P}<$ $0.05)$.

\section{DISCUSSION}

Some evidence for behavioral stereotypy of naticids was present in the Eocene of the Coastal Plain. In particular, intraspecific size stereotypy appears to have been better developed in the Eocene than was selectivity of prey species.

Nine of the eleven species examined showed intraspecific prey size selectivity, as evidenced by significant correlations between prey size and outer borehole diameter. All categories of drillholes exhibited significant correlations with prey size for Venericardia horatiana (Bashi), Callista perovata and Lucina pomilia (Piney Point), Pachecoa decisa (upper Lisbon), and Gonimyrtaea subcurta and Spisula jacksonensis (Moodys Branch). These species also had very high (typically $100 \%$ ) drilling success rates. These results accord well with those of Kelley (1988) for the Maryland Miocene. In general, species from the Chesapeake Group showed a strong relationship between drilling success and selectivity of drillhole site and prey size; a significant rank correlation was found between predation success and degree of size selectivity (expressed by the correlation coefficient of OBD and L) for nine Chesapeake Group species. Kelley (1988) suggested that such behavioral stereotypy increased the predator's chances for success. The same conclusion appears warranted for the Eocene.

Two species, Gonimyrtaea curta and Corbula subengonata, showed no significant relationship between drillhole size and prey size. In two additional species (the corbulids Vokesula aldrichi and Caestocorbula wailesiana), size of complete and functional holes was correlated with prey size, but the correlation for all holes was nonsignificant. Thus, when incomplete holes were included in the analysis, the correlation coefficient decreased drastically. Results were similar for the Miocene Chesapeake Group fauna studied by Kelley (1988). Because incomplete drillholes may result from the predator attacking too large a prey 
item, it is reasonable that inclusion of incomplete holes would decrease the correlation of predator and prey size (Kelley, 1988). Vokesula aldrichi also showed a nonsignificant correlation between OBD and L for normally sited holes. This result was contrary to our expectations, because abnormally sited holes, which may result from attacks on inappropriately sized prey, were excluded from the regression. The decreased correlation for normally sited holes may result from the smaller sample of such holes in this corbulid species. Alternatively, the lack of correlation for normally sited holes may reflect anomalous patterns of drilling on corbulids, as was observed by Kelley (1988) and Kelley and Hansen (1993).

Corbulid species also appear to be unusual in the high frequency of unsuccessful drilling present in these Eocene samples. Although corbulids generally were common victim taxa in our Paleogene predation survey (Kelley and Hansen, 1993; Hansen and Kelley, 1995), drilling success rates were relatively low. In this analysis, success rates on corbulids were significantly less than on non-corbulid taxa (Table 1; overall success rate of $76.2 \%$ on corbulids, $96.7 \%$ on non-corbulids; $\chi^{2}=39.16 ; \mathrm{P}<0.001$ ). Kelley (1988) also found drilling on Corbula to be anomalous, with lower rates of drilling success, less developed selectivity of prey size and drillhole site, and drilling frequencies inconsistent with cost-benefit predictions. These anomalies were attributed to the presence of a conchiolin layer within the corbulid shell that may act as a deterrent to predation (Kelley, 1988; but see Anderson, 1992, for alternative explanations for anomalous predation).

The results of cost-benefit analysis do not compare as favorably with studies of Neogene and Recent assemblages, in which naticid predation was generally predictable (Kitchell et al., 1981; Kelley, 1988, 1991). Only in the Bashi Member were actual drilling frequencies generally consistent with cost-benefit predictions; our results for the Bashi are similar to those of Kitchell (1982), who performed cost-benefit analyses on two species of bivalve prey from the Bashi. In the Piney Point Formation, prey items were drilled at equivalent frequencies regardless of predicted rank. Upper Lisbon and Moodys Branch results show some items were drilled at the expected level, but several significant departures from the predictions also occurred. For instance, in the Moodys Branch Formation, Spisula jacksonensis was drilled at much lower frequencies than predicted by cost-benefit analysis.

The common departure of observed drilling frequencies from predictions made by cost-benefit analyses of the Piney Point, upper Lisbon, and Moodys Branch Formations suggests that prey selectivity was not as well developed in the middle and late Eocene as it was in the Neogene and the Recent. Before accepting this conclusion, however, alternative explanations for the discrepancies between predicted and actual drilling should be considered. One alternative is that predicted prey preferences may not be met in the Eocene because cost-benefit analysis explicitly accounts only for shell thickness, internal volume, and predator/prey sizes. Other factors, such as rapid or deep burrowing, shell microstructure, or chemical defenses, are not included in the analysis but may confer drilling resistance (e.g., the previously mentioned conchiolin layer in corbulids; Kelley, 1988).

Perhaps previous cost-benefit studies more successfully predicted naticid preferences because the prey species examined had similar life habits. All of the bivalve prey examined by Kitchell et al. (1981; Mya, Mercenaria, Mytilus, Chione, Glycymeris) and Kelley (1988; Astarte, Eucrassatella, Lucina, Corbula, Anadara) were slow burrowers, as evidenced by their strong concentric or radial ornament, large cross section, and behavior of modern representatives (Stanley, 1970; L. Anderson and E. CoBabe, personal communication). On the other hand, two of the genera examined in this study that departed significantly from costbenefit predictions, Callista and Spisula, have smooth, streamlined, low-convexity shells indicative of rapid burrowing. Drilling could be low on Spisula and Callista, despite a favorable cost-benefit ratio, simply because the prey were very active. Such rapidly burrowing taxa may be difficult to capture, although once captured they appear to be drilled successfully (Table 1).

Nevertheless, there is relatively poor correspondence between cost-benefit predictions and actual drilling frequencies, even among slow burrowers in our samples. Selectivity and behavioral stereotypy of naticids in the Eocene thus appear to have been less developed than in Neogene and Recent assemblages. This result is consistent with our hypothesis that naticid predator-prey interactions differed earlier in the history of the family compared to later, and corroborates the hypothesis of escalation.

The poorly developed interspecific prey selectivity observed in these assemblages contrasts with the well-developed intraspecific prey size selectivity. These results suggest that naticids are better able to evaluate the size of a prey item than they are to recognize its cost-benefit parameters.

\section{CONCLUSIONS}

1) Intraspecific prey size selectivity by naticids occurred for nine of eleven Eocene bivalve species. Some taxa showed a stronger relationship between predator and prey size for functional holes than when unsuccessful holes were also included, perhaps because incomplete holes result from a mismatch of predator and prey sizes.

2) Drilling success rates were generally high, with the exception of predation on corbulids. Success rates for corbulids were $76 \%$, compared to $97 \%$ for non-corbulids; the difference is statistically significant.

3) Cost-benefit analysis successfully predicted predation within the Bashi Member of the Hatchetigbee Formation. However, drilling departed significantly from cost-benefit predictions for the Piney Point, upper Lisbon, and Moodys Branch Formations. These results indicate that prey selectivity by naticids was less developed in the Eocene than in the Neogene or Recent, in accordance with the hypothesis of escalation. 


\section{ACKNOWLEDGMENTS}

We thank Robert Sickler and Vicky Andrews for assistance with data tabulation and analysis and Geerat Vermeij and an anonymous reviewer for helpful reviews. Sup port for this study was provided by National Science Foundation grant EAR 8915725 to Kelley and Hansen and collaborative grants EAR 9405104 (Kelley) and EAR 9406479 (Hansen). Hansen also acknowledges support from the Bureau of Faculty Research at Western Washington University.

\section{REFERENCES}

ANDERSON, L.C., GEARY, D.H., NEHM, R.H., and Allmon, W.D., 1991, A comparative study of naticid gastropod predation on Varicorbula caloosae and Chione cancellata, Plio-Pleistocene of Florida, USA: Palaeogeography, Palaeoclimatology, Palaeoecology, v. 85, p. 29 46.

ANDERSON, L.C., 1992, Naticid gastropod predation on corbulid bivalves: Effects of physical factors, morphological features, and statistical artifacts: PALAIOS, v. 7, p. 602-617.

$\rightarrow$ BogGS, C.H., RICE, J.A., KITCHELl, J.A., and Post, W.M., 1984, Predation at a snail's pace: What's time to a gastropod?: Oecologia, v. 62, p. 13-17.

BROMLEY, R.G., 1981, Concepts in ichnotaxonomy illustrated by small round holes in shells: Acta Geologica Hispanica, v. 16, p. 5564.

CARRIKER, M.R., 1981, Shell penetration and feeding by naticacean and muricacean predatory gastropods: A synthesis: Malacologia, v. 20 , p. $403-422$.

EDWARDS, D.C., 1974, Preferred prey of Polinices duplicatus in Cape Cod inlets: Bulletin of the American Malacological Union, v. 41,p. 17-20.

ELDER, S.R., and HANSEN, T.A., 1981, Macrofossil assemblages of the Moodys Branch Formation (Upper Eocene), Louisiana and Mississippi: Mississippi Geology, v. 2, p. 6-11.

$\rightarrow$ HANSEN, T.A., and KELLEY, P.H., 1995, Spatial variation of naticid gastropod predation in the Eocene of North America: PALAIOS, v. 10, p. 268-278.

$\rightarrow$ Kelley, P.H., 1988, Predation by Miocene gastropods of the Chesa- peake Group: Stereotyped and predictable: PALAIOS, v. 3, p. 436448.

KELLEY, P.H., 1991, Cannibalism by Chesapeake Group naticid gastropods: A predictable result of stereotyped predation: Journal of Paleontology, v. 65, p. 75-80.

KELlEY, P.H., and HANSEN, T.A., 1993, Evolution of the naticid gastropod predator-prey system: An evaluation of the hypothesis of escalation: PALAIOS, v. 8, p. 358-375.

KITCHELL, J.A., 1982, Coevolution in a predator-prey system: Proceedings of the North American Paleontological Convention III, v. 2, p. 301-305.

KITCHELL, J.A., 1986, The evolution of predator-prey behavior: Naticid gastropods and their molluscan prey: in NITECKI, M., and KITCHELL, J.A., eds., Evolution of Animal Behavior: Paleontological and Field Approaches: Oxford University Press, Oxford, p. 88110.

KITCHELl, J.A., BoGGS, C.H., KITCHELL, J.F., and RICE, J.A., 1981, Prey selection by naticid gastropods: Experimental tests and application to the fossil record: Paleobiology, v. 7, p. 533-552.

KITCHELl, J.A., BogGS, C.H., RICE, J.A., KITCHELl, J.F., HoffmaN, A., and MARTINELL, J., 1986, Anomalies in naticid predatory behavior: A critique and experimental observations: Malacologia, v. 27, p. 291-298.

KowALEWSKI, M., 1993, Morphometric analysis of predatory drillholes: Palaeogeography, Palaeoclimatology, Palaeoecology, v. 102, p. 69-88.

RoY, K., Miller, D.J., and LABARBERA, M., 1994, Taphonomic bias in analyses of drilling predation: Effects of gastropod drill holes on bivalve shell strength. PALAIOS, v. 9, p. 413-421.

$\rightarrow$ SoHL, N.F., 1969, The fossil record of shell boring by snails: American Zoologist, v. 9, p. 725-734.

STANLEY, S.M., 1970, Relation of Shell Form to Life Habits of the Bivalvia (Mollusca): Geological Society of America Memoir 125, $296 \mathrm{p}$.

VERMEIJ, G.J., 1987, Evolution and Escalation: An Ecological History of Life: Princeton University Press, Princeton, 527 p.

VERMEIJ, G.J., 1994, The evolutionary interaction among species: selection, escalation, and coevolution: Annual Review of Ecology and Systematics, v. 25, p. 219-236.

WILTSE, W.I., 1978, Effects of predation by Polinices duplicatus on community structure [Ph.D. thesis]: University of Massachusetts.

ACCEPTED JUNE 25, 1995 